\author{
Reconnaissance geology of the Ar Rawdh quadrangle, sheet $26 / 400$, \\ Kingdom of Saudi Arabia \\ by \\ J. M. O'Nei $\frac{1 /}{1 / 1}$ and D.C. Fer $\frac{1 /}{\text { ris }}$
}

Open-File Report $85-659$

\footnotetext{
Report prepared for Ministry of Petroleum and Mineral Resources, Deputy Ministry for Mineral Resources, Saudi Arabia
}

This report is preliminary and has not been reviewed for conformity with U.S. Geological Survey editorial standards and stratigraphic nomenclature.

I/ U.S. Geological Survey, Denver, CO 


\section{CONTENTS}

Page

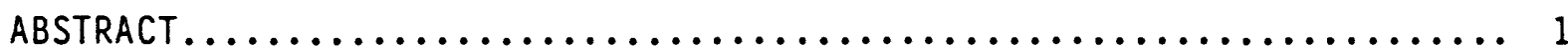

INTRODUCTION............................................ 2

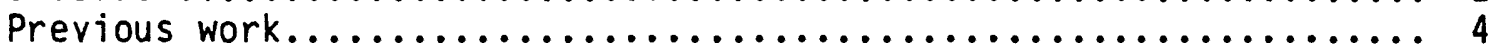

Acknowledgments....................................... 4

GEOLOGIC SETTING....................................... 5

PROTEROZOIC VOLCANIC AND SEDIMENTARY ROCKS..................... 6

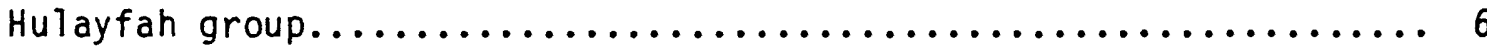

Basaltic rocks..................................... 6

Andesite and basalt and related rocks..................... 7

Sedimentary and volcanic rocks, undivided................. 7

Shammar group........................................ 8

Kuara formation...................................... 8

Matha formation..................................... 8

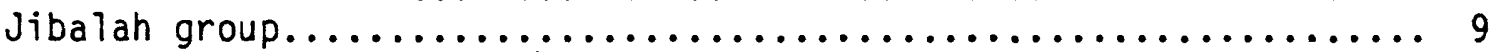

PROTEROZOIC INTRUSIVE ROCKS $\ldots \ldots \ldots \ldots \ldots \ldots \ldots \ldots \ldots \ldots \ldots \ldots \ldots \ldots \ldots \ldots$

Mafic intrusive rocks...................................... 10

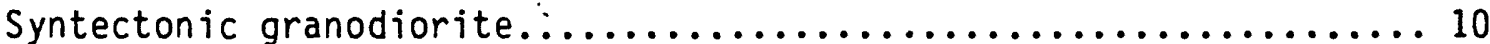

Hornblende granodiorite................................ 10

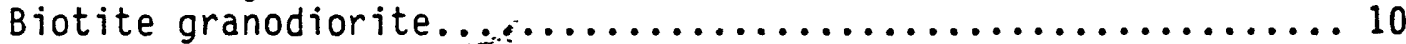

Quartz diorite....................................... 10

Gneiss and migmatite....................................... 11

Granite and Pegmatite................................... 11

Granophyre and related rocks................................. 11

Granitic rocks........................................... 12

Monzogranite........................................ 12

Alkali-feldspar granite................................. 12

Rhyolite and aplite.................................... 12

Felsic to mafic dikes and sills.......................... 13

CENOZOIC DEPOSITS......................................... 14

Quaternary-Tertiary basalt............................... 14

Quaternary deposits.................................. 14

STRUCTURE........................................... 15

ECONOMIC GEOLOGY............................................ 17

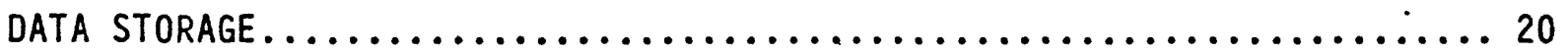

REFERENCES CITED..................................... 21

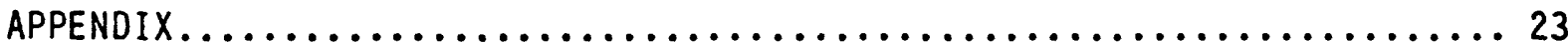




\section{ILLUSTRATIONS}

Plate 1. Reconnaissance geologic map of the Ar Rawdh quadrangle..................... in pocket

Figure 1. Index map of western Saudi Arabia.................. 3

2. Geologic sketch map of the Ar Rawdh quadrangle............ 18

Table 1. Semiquantitative and wet chemical laboratory analyses...... 19

Appendix Stratigraphic sections of the upper part of the

Kuara formation (A) and the upper and lower parts

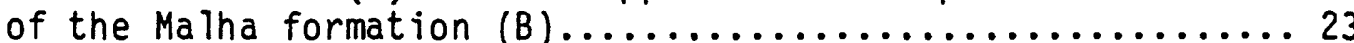




\title{
RECONNAISSANCE GEOLOGY OF THE \\ AR RAWDH QUADRANGLE, SHEET 26/40 D, \\ KINGDOM OF SAUDI ARABIA
}

\author{
By \\ J. M. O'N $\frac{1 /}{\text { eill }}$ and D. C. Ferrits
}

\begin{abstract}
The Ar Rawdh quadrangle $(26 / 40 \mathrm{D})$ is located $150 \mathrm{~km}$ southwest of Ha'il between lat

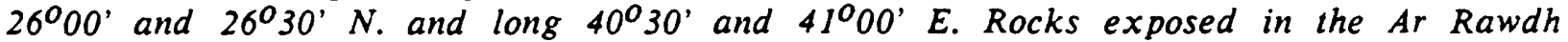
quadrangle consist almost entirely of late Proterozoic igneous, sedimentary, and metamorphic rocks that can be divided into three major groupings. The oldest rocks consist of steeply-dipping, north-trending volcanic, volcaniclastic, and sedimentary rocks correlative with Hulayfah group rocks to the south and greenschist facies rocks to the north and east. These rocks were deformed and metamorphosed to the greenschist facies during their accretion onto the Arabian-Nubian shield. Small bodies of serpentinite and basalt dike swarms appear to occur as tectonic slices in the Hulayfah group rocks and may be remnants of an ophiolite sequence emplaced at this time. Within the quadrangle, this accretionary event was accompanied by intrusion of granodioritic plutons that metamorphosed, migmatized, and recrystallized the ad jacent host rocks.
\end{abstract}

A sequence of sedimentary and felsic volcanic rocks, loosely correlated with the Shammar group rocks, rests unconformably above these basement rocks. Massive rhyolitic ash-flow tuffs in the northeast and west-central parts of the map area appear to be lateral equivalents of a mixed sedimentary and felsic volcanic sequence in the central part of the quadrangle. The youngest Proterozoic sedimentary and volcanic rocks known from the shield, the Jibalah group, are also present in the quadrangle and are exposed in a major northwest-trending graben associated with the Najd fault system. These rocks may also be equivalent to the upper part of those rocks correlated with the Shammar group.

The youngest Proterozoic rocks in the map area are represented by a series of posttectonic alkali-rich plutons that were passively intruded into all older rock sequences.

A series of northwest-trending strike-slip faults that show more than $30 \mathrm{~km}$ left lateral separation is the major structural feature in the map area. These faults also appear to have formed minor but important basins of deposition during Shammar time and to have localized some of these volcanic and sedimentary deposits.

Rocks of the Ar Rawdh quadrangle show clear evidence of weak hydrothermal mineralization, but economic mineral deposits apparently did not form in the area. Stratabound sulfide deposits, formed during volcano-exhalative episodes associated with island arc terranes, and occuring elsewhere in the Arabian Shield, are apparently absent from Hulayfah group rocks in this area.

If U.S. Geological Survey, Denver, co 


\section{INTRODUCTION}

The Ar Rawdh Quadrangle (fig. 1), named for the largest village in the map area, centers $150 \mathrm{~km}$ southwest of Ha'il and is directly north of the village of Hulayfah in the northern Hijaz region of Saudi Arabia. The quadrangle lies between lat. $26^{\circ} 00^{\prime}$ and $26^{\circ} 30^{\circ} \mathrm{N}$. and long. $40^{\circ} 30^{\prime}$ and $41^{\circ} 00^{\prime} \mathrm{E}$. and encompasses an area of over $2800 \mathrm{sq} \mathrm{km}$.

Two major wadi systems, the combined Wadi Asmarah-Wadi Qahd and the Wadi Ar Rumah, flow southeast through the quadrangle. The combined Wadis Asmarah-Qahad form a braided stream channel and sebkha drainage system that is more than $8 \mathrm{~km}$ wide, as they cross the central part of the map area. The three wadi systems, whose headwaters are within the confines of the adjacent quadrangles, merge near the southeastern corner of the Ar Rawdh quadrangle and form one of the major east flowing drainages on the Saudi Arabian shield. North of the Wadi Asmarah, in the northeastern corner of the map area, monolithic granite jabals surrounded by large alluvial aprons rise abruptly from the beveled surface rocks of the plains. The area lying between Wadi Ar Rumah and Wadi Asmarah is one of mixed topographic relief: low hills of reddish-orange and dark-green hues are surrounded by flat plains of a dark-greenish to reddish-brown casts. Granite and rhyolite jabals arise above the weakly eroded plains south of the Wadi Ar Rumah. Fingers of Cenozoic basalt of the Harrat Khaybar, which covers large portions of the area to the west, invade the map area along its western border.

The authors mapped the area in reconnaissance at a scale $1: 100,000$ during a five-week period in December 1983 and January and February 1984. Initial access to the quadrangle can be made by way of the Medina-Ha'il highway, a major paved road running northeast through the southeast part of the quadrangle. Further access is primarily through numerous unimproved dirt tracks and graded service roads.

The climate is typical of desert areas of lower latitudes, with hot summers and cool winters. Rainfall, although scant, occurs mostly in the early Spring and late Autumn months. Water resources and associated vegetation are sparse and primarily restricted to major wadi channels and the perimeter of the Cenozoic basalt fields. In both instances small farming communities are found. The largest permanent settlements are Durayghit and Ar Rawdh, in the northwest and southwest parts of the quadrangle, respectively.

The work was performed in accordance with a work agreement between the U.S. Geological Survey and the Ministry of Petroleum and Mineral Resources, Kingdom of Saudi Arabia. 


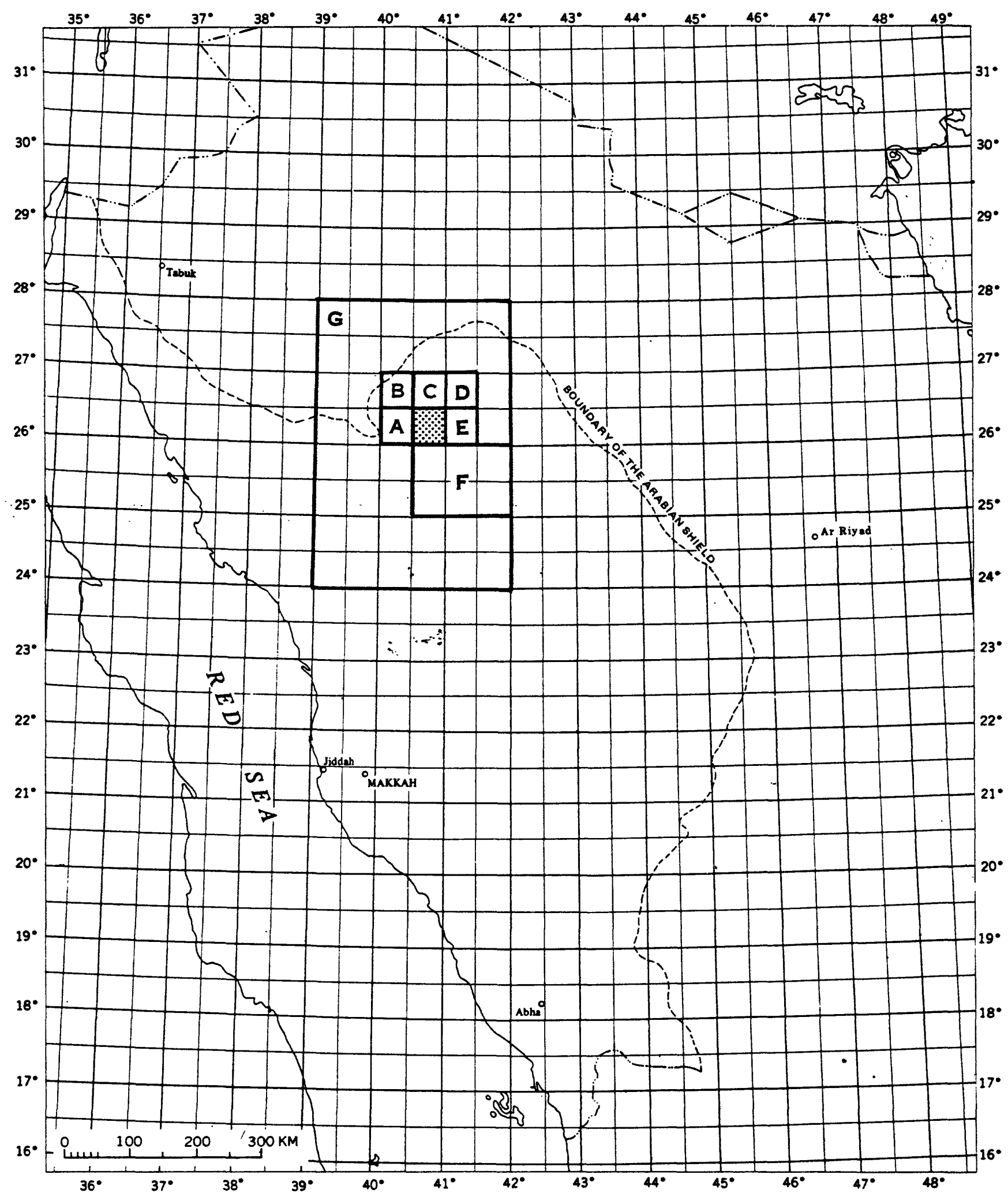

Figure 1.- Index map of western Saudi Arabia showing the location of the Ar Rawd quadrangle (patterned) and other quadrangles referred to in this report: A, Jabal al Usayfir (Fairer, 1985a); B, Ash Shamila (Fairer,. 1985b); C, Zarghat (Quick, 1984); D, Ghazzalah (Quick, 1983); E, As Sulaymi (Quick, 1985); F, Nuqrah (Delfour, 1977); and G, Northeastern Hijaz (Brown and others, 1963). 


\section{PREVIOUS WORK}

The Ar Rawdh quadrangle was first mapped by Brown and others (1963) as a part of the reconnaissance map of the Hulayfah-Zarghat area by Bowden (1982) (fig. 1). The area directly south of the Ar Rawdh quadrangle was mapped and compiled by Delfour (1977) for the Nuqrah 1:250,000 sheet. Geologic maps of the thirty-minute quadrangles directly west and north west of the map area were prepared by Fairer $(1985 \mathrm{a}, \mathrm{b})$ of the USGS; geologic maps of the quadrangles directly north, and east of the quadrangle were prepaired by Quick (1983, 1984, 1985), also of the USGS.

An aeromagnetic survey of the quadrangle was performed by a consortium of geophysical survey companies under the supervision of BRGM as part of a shield-wide geophysical project. A recent geochemical reconnaissance of the quadrangle was performed by W. Miller of the USGS (written comm., 1984).

\section{ACKNOWLEDGMENTS}

This work was performed in accordance with a work agreement between the U.S. Geological Survey and the Ministry of Petroleum and Mineral Resources, Kingdom of Saudi Arabia. 


\section{GEOLOGIC SETTING}

The Ar Rawdh quadrangle encompasses part of the northern region of the Precambrian Shield of Saudi Arabia. The Arabian Shield, and the once contiguous Nubian Shield of northeast Africa, composed a large cratonic area that was formed by successive east-to-west accretions of island-arc terranes between 1000 and $700 \mathrm{Ma}^{\prime \prime}$ ? (Greenwood and others, 1976; Schmidt and others, 1979). The Arabian Shield is. composed partly of older, primitive metamorphic and plutonic crustal rocks that can be divided into north-trending segments separated by crustal sutures. These sutures are marked by narrow zones of ophiolitic rock types (Frish and Al-Shanti, 1977). All rocks ${ }^{\circ}$ were deformed into steeply dipping, north-trending fold and thrust belts, metamorphosed to the greenshcist facies during the collision of island-arc terranes, and were locally injected by weakly foliated gabbroic to trondjhemitic rocks that accompanied the late tectonic stages of accretion (Schmidt and others, 1979). Uplift and erosion preceeded the intrusion of numerous post-tectonic plutons in the shield. The intrusion of some of these rocks was accompanied by deposition of the mainly volcanic Shammar group rocks in the west and the mainly clastic sedimentary Murdama group rocks in the east (Delfour, 1977; Kemp and others, 1980). Deposition and intrusion was apparently preceeded by some left-lateral strike-slip faulting along the transArabian $\mathrm{Najd}$ fault system (Cole and O'Neill, 1985) which ended about $560 \mathrm{Ma}$ ago. Cumulative left lateral displacement on on this fault system is nearly $300 \mathrm{~km}$ (Schmidt and others, 1979). The newly formed craton was then transgressed by early Paleozoic seas. Rifting of the Arabian-Nubian Shield began in Miocene time, resulting in down-to-the-west normal faulting parallel and adjacent to the zone of separation, accompanied by isostatic rise and basaltic volcanism along the rifted margins and forming of the present day Red Sea. 


\section{PROTEROZOIC VOLCANIC AND SEDIMENTARY ROCKS}

Proterozoic volcanic and sedimentary rocks exposed in the Ar Rawdh quadrangle consists of two major groups. The oldest group consists of a medium- to dark-green, steeply dipping layered sequence of alternating basic to intermediate volcanic rocks interlayered with volcaniclastic and minor carbonate sedimentary rocks. The youngest group, which rests unconformably on the older sequence, consists of red-brown, horizontal to gently folded intermediate to felsic ash flows interlayered $y$ ith fine- to coarse-grained clastic and minor carbonate sedimentary rocks. (see pl. /).

The older group is correlative and continuous with the Hulayfah group, mapped and described in the adjacent Nuqrah quadrangle to the south (Delfour, 1977), and equivalent to the greenstones mapped to the north and east of the Ar Rawdh quadrangle by Quick $(1983,1984,1985)$.

The younger group is broadly equivalent to the Shammar group of Brown and others, (1963), to the Shammar and Jibalah groups of Delfour, (1977) in the Nuqrah quadrangle to the south, and to felsic and intermediate volcanic rocks and associated sedimentary rocks mapped by Quick $(1983,1984,1985)$ to the north and east.

\section{HULAYFAH GROUP}

The Hulayfah group, mapped by Delfour (1977) directly south of the Ar Rawdh Quadrangle, consists of two formations containing both volcanic and sedimentary rock assemblages that are interpreted to overlie the Urd group ophiolite complex. The ophiolite complex, locally well-exposed in the southern parts of the Nuqrah quadrangle, consist of serpentinized ultramafic rocks associated with anorthosite and lenses of dunite, serpentine, gabbro, siliceous dolomitic listwanite, and pillowed and amygdaloidal andesite and basalt (Delfour, 1977, p. 7). This belt thins and splits in the north of the Nuqrah quadrangle where it is characterized by the predominance of basaltic dikes (Frish and Al-Shanti, 1977, p. 299). Urd group rocks are bounded on the east and the west by Hulayfah group rocks.

Rocks equivalent to the Hulayfah Group and possible tectonic slices of the underlying Urd group, are present but poorly exposed in the Ar Rawdh quadrangle. Almost all exposures are confined to broad, flat areas and are commonly covered by thin alluvial deposits, lag gravels, or colluvium. These rocks are divided into three main groups whose relative age relations are not clear in this map area: 1) a predominantly sedimentary sequence of volcaniclastic rocks and associated, well-layered limestone; 2) a predominantly andesitic to basaltic volcanic sequence associated with polymictic conglomerate; and 3) a nonlayered sequence of basaltic rocks. These map units may be broadly equivalent to Delfour's Nuqrah formation and Af na formation of the Hulayfah group and the ultramafic Urd formation, respectively.

\section{Basaltic rocks}

Dark-greenish-black, massive, and non-layered to weakly layered basaltic rocks (hb) present in the quadrangle may represent large tectonic slices of Urd group rocks. They are locally amygdaloidal, but no pillow structures were observed. The basaltic rocks are closely associated with complexly interlayered mafic sills and dikes (hbp) and with layered andesitic to basaltic volcanic rocks associated with polymictic conglomerate (hab). 
The basaltic rocks show in selected thin sections a very fine grained, altered groundmass that is largely chlorite and microcrystalline quartz. Rectangular areas of fine-crystalline quartz and minor chlorite may represent relict phenocrysts. Rounded. zones filled with coarse-crystalline, inward-radiating chlorite, and some quartz, and less commonly calcite, appear to be former amygdules.

\section{Andesite and basalt and related rocks}

Weakly layered to well-layered andesitic to basaltic volcanic rocks that are invariably associated with volcanic breccia and polymictic conglomerate compose the most widespread greenstone unit (hab) of the Hulayfah group. This map unit is the most poorly exposed layered sequence in the quadrangle, and is probably lithologically more complex than described. Most exposures are restricted to the central part of the quadrangle between the Wadi Asmarah and Wadi Ar Rumah. The rocks are medium- to dark-green, fine-grained, layered volcanic flows containing minor plagioclase phenocrysts. Some flows are weakly vesicular. Polymictic conglomerate is common, and consists of lithologically diverse angular to subrounded clasts as large as $6 \mathrm{~cm}$ in diameter. Clast composition varies from diorite to granodiorite to vesicular basalt. These rocks are seen in thin section to be strongly altered to chlorite; silicification of the unit is pervasive.

Minor lenses and layers of gray to tan siliceous, dolomitic marble (hn), gray chert (hs), and blue-green serpentinite (hsp) are associated with andesite, basalt, and polymictic conglomerate.

A single, grey to tan, fine-to coarse-crystalline marble horizon in the central part of the map area, of fet numerous times by left-lateral displacement along various strands of the Najd fault system, has a total length of nearly $10 \mathrm{~km}$. This and similar marbles, generally less than 25-50 meters in thickness, weather gray, tan, and pink; exposed surfaces are exceedingly rough and irregular and layering is difficult to define. The rock is extremely hard and dense, and appears to be strongly deformed. Locally, angular ghosts of replaced volcanic breccia fragments are present. In thin section the rock is seen to contain mostly calcite, minor quartz, and variable amounts of chlorite. Rectangular- to wedge-shaped aggregates of chlorite and large, blocky areas defined by pods of chlorite, may outline former mafic mineral phases. These rocks may be partly equivalent to the siliceous dolomitic listwanite present in the Nuqrah quadrangle to the south (Delfour, 1977).

Linear siliceous zones of fine-grained, light- to medium-gray quartz (hs) are present in the hab unit. These lenses are commonly less than $0.75 \mathrm{~km}$ long, 3-10 meters thick, and are brecciated and infilled with drusy quartz.

Serpentinite (hsp), found only in one locality near the center of the quadrangle, is interlayered with mafic volcanic rocks of the hab unit. The exposures are nearly buried by brown-red alluvial gravels and stand out as small, bright- bluish-green weather resistant knobs. The serpentinite is strongly fractured and broken in outcrop. In thin section it is seen to consist of antigorite, veinlets of opaque oxides, blocky patches of carbonate, and unaltered red spinel (?).

\section{Sedimentary and volcanic rocks, undivided}

A mixed sequence of rocks characterize the Hulayfah group exposed in the south part of the map area. These rocks weather medium-green, are well layered, and contain gray to tan lenses of carbonate, most of which are of certain sedimentary origin. The 
noncarbonate rocks (hsv) consist of interlayered andesitic tuff, parallel laminated siltite and argillite, very fine grained lithic sandstone, and weakly layered andesitic rocks. Felsic to intermediate volcanic rocks are present but are not common. Limestone lenses (hl) are common, and consist of medium to bluish-gray, generally fine grained, well layered carbonate with locally abundant black chert lenses and nodules.

\section{SHAMMAR GROUP}

The Shammar rhyolite, a name originally and loosely applied to rhyolitic rocks by Brown and Jackson (1960), was recognized as a diverse group of felsic volcanic and clastic sedimentary rocks by Schmidt and others (1973), and Hadley (1973). Rocks that unconformably rest on the greenstones of the Hulayfah group, and that are broadly equivalent to the Shammar group, are present in the Ar Rawdh quadrangle. These rocks can be divided into at least four mappable units, some of which may be lateral facies of the same time-stratigraphic sequence.

South of the Ar Rawdh quadrangle, and in the western part of the Nuqrah quadrangle (Delfour, 1977), the Shammar Group is divided into two formations: the basal sedimentary Kuara formation; and the overlying, mainly volcanic Malha formation. The Jibalah group, defined from exposures in the Nuqrah quadrangle (Delfour 1970) was interpreted to have been deposited in graben-like depressions formed along the Najd fault system in post-Shammar time.

\section{Kuaka Formation}

The lowest mappable unit of the Shammar group in the Ar Rawdh quadrangle rests unconformably on the Hulayfah group and is an incompletely exposed clastic sedimentary sequence (skc) consisting of basal, coarse, greenish, boulder to pebble conglomerate and an uppermost sequence of mainly sandstone and shale; very minor, thin rhyolitic flows are locally present near the top. The conglomerate is best exposed in the southwest corner of the map area and consists of pebble- and boulder-sized clasts derived from the underlying chloritized Hulayfah group rocks. Clasts of diorite to granodiorite, basic aphanitic volcanic rocks, and green, volcaniclastic rocks contained in a sandy matrix are the principle components of the conglomerate. Minor, fine-grained, lithic sandstone, and calcareous sandstone and siltstone are locally interlayered with the conglomerate. The upper part of the section (sk) was measured at Jibal Tuluf and is described in the appendix. The section consists of interbedded conglomerate, sandstone, and shale. The top of the unit is taken at the first, thick, thyolite flow breccia; however a major unconformity is present between these flow breccias and the overlying welded tuff and may more aptly mark the top of the Kuara formation. This unit is equivalent to the Kuara formation exposed and mapped in the Nuqrah quadrangle to the south (Delfour, 1977).

\section{Malha Formation}

The Kuara formation is overlain by mainly. felsic volcanic rocks that appear to show lateral facies changes. Southwest of the Rawdh fault, these rock consist of massive, thick, rhyolitic to rhyodacitic flows. Between the Rawdh and Asmarah-Qahad faults, flows that appear to be equivalent to the massive flows in the southwest part of the quadrangle, are thinner and are interlayered with sedimentary rocks. Farther northeast, across the Asmarah fault, these rocks are characterized by massive rhyolitic to rhyodacitic flows that rest directly on the beveled surface of the essentially vertical Hulayfah group. These rocks, even though they have a slightly different character 
across the Najd fault system in the quadrangle, are similar and appear correlative. If : correlated with rocks in the Nuqrah quadrangle to the south, they would be part of the Malha formation. The Malha formation in the Ar Rawdh quadrangle is divided into. two facies; intercalated felsic volcanic flow and sedimentary rocks (sm), and a largely volcanic sequence that consists mainly of massive, cliff forming, crystalithic tuffs (smv). A partial measured section of the lower and upper parts of the Malha formation is given in the appendix.

\section{JIBALAH GROUP}

The Jibalah group, first recognized and mapped by Delfour $(1970,1977)$ in the Nuqrah quadrangle as the youngest sedimentary unit of the Proterozoic, consists of conglomerate, sandstone, limestone, and shale interlayered with alkali basalts. These rocks are interpreted to have been deposited in narrow, northwest-trending, fault-bounded basins along the Najd fault system. The Sima'iyah syncline that contains Jibalah group rocks in the north-central part of the Nuqrah quadrangle is structurally continuous with the Asmarah-Qahad graben in the Ar Rawdh quadrangle. The Asmarah-Qahad graben contains a unique sedimentary sequence like the Sima'iyah" syncline to the south. However, the rocks in the Ar Rawdh quadrangle are not. interlayered with basaltic rock, but with rhyolitic ash flows that are similar to flows associated with the nearby Malha formation. These rocks can be traced northward into the adjacent Zarghat quadrangle and were mapped by Quick (1984) as the informal Zarghat formation. Rocks included in the Jibalah group consist of coarse, reddish-tan, loosely cemented, pebble and cobble conglomerate (jc) with clasts consisting almost entirely fine-grained, felsic volcạaic rocks and coarse-grained, alkali-rich plutonic rocks. The conglomerate is thickest in the south where it is interlayered with fine- to coarse-grained, lithic-rich sandstone, green to maroon shale, and silicified, locally cherty oolitic to laminated limestone (js). This largely sedimentary sequence is interlayered with minor rhyolitic flows in the south, but appears to be overlain, or in part, laterally equivalent to, a thick section of silicic volcanic tuffs and flows interlayered with pinkish-red sandstone, shale, and minor conglomerate $(\mathrm{jr}, \mathrm{jb})$ in the north. 


\section{PROTEROZOIC INTRUSIVE ROCKS}

\section{MAFIC INTRUSIVE ROCKS}

Small stocks, dikes, and sills of medium- to coarse-crystalline diorite to gabbro (hbp) have intruded Hulayfah group rocks and appear to be closely tied to their evolution. Most of these intrusive rocks were not mapped separately from their volcanic host because of commonly strong compositional similarities between host and intrusive, the lack of definite outcrop pattern, and the scale of mapping. Areas containing these rocks generally stand as low, segmented, linear hills of dark-green to black, massive rock. The rocks are generally coarse crystalline and non layered. Locally, as in the east central part of the map area, the intrusives are so closely spaced as to suggest a sheeted-dike complex, either deformed along with the enclosing Hulayfah group, or intruded along tectonic trends within the Hulayfah. In thin section, most rocks are seen to be equigranular and weakly porphyritic. They consist of locally zoned andesine to labradorite and prisms of diopside and hornblende in various stages of alteration to chlorite. Minor euhedral magnetite is common.

\section{SYNTECTONIC GRANODIORITE}

A north-trending zone of granodioritic rocks that weathers to white, grus-covered surfaces of low relief, is present along the western part of the map area. Outcrops appear to define a linear, north-trending, composite pluton that was intruded late in the tectonic cycle that deformed the enclosing Hulayfah group rocks. The syntectonic character of the pluton is indicated by the migmatized, recrystallized, and weakly foliated wall rock adjacent to the fintrusive body, and by the generally conformable contact relations with the enclosing layered rocks.

\section{Hornblende granodiorite}

The pluton is composed principally of hornblende granodiorite (hgd) in the southern part of the quadrangle where it consists of essential andesine to oligoclase plagioclase, euhedral green pleochroic hornblende, commonly altered to chlorite and opaque oxides, and strained anhedral quartz commonly displaying sutured contacts with adjacent grains.

\section{Biotite granodiorite}

The northern two-thirds of the pluton, which is cut and of fset by nearly $15 \mathrm{~km}$ to the northwest by the Rawdh fault, consists mainly of biotite granodiorite (bgd). This rock is generally inequigranular and consists of subhedral to euhedral, sericitized oligoclase set in a slightly finer crystalline matrix of equant to weakly granoblastic quartz, tabs of biotite partly altered to opaque oxides and sericite, minor muscovite, and potassium feldspar that is either confined to veinlets, or occurs as interstitial anhedral crystals that have partly replaced adjacent grains.

\section{Quartz diorite}

A small body of quartz diorite (qd), interpreted to be part of this pluton, is present in the west-central part of the map area. This rock consist principally of sericitized, zoned andesine, pale-green, pleochroic, subhedral hornblende, and anhedral, interstitial quartz. 


\section{Gneiss and migmatite}

The enclosing metamorphic rocks (hgn) generally show weak to well-developed foliation. The rocks represent recrystallized Hulayfah group rocks of both sedimentary and igneous origins. The more gneissic samples examined in thin section show well-developed foliation defined by granoblastic, elongate quartz, alignment of hornblende prisms, locally alternating fine- and coarse-crystalline layers, and elongate zones or lenses rich in opaque oxides. Strained quartz is common and grains display sutured and diffuse grain boundaries. Plagioclase is sericitized.

\section{Granite Pegmatite}

The hornblende and biotite granodiorite are closely associated with small to large (1 $\mathrm{m}$ to $1 \mathrm{~km}$ diameter) pods of quartz-rich granite pegmatite ( $\mathrm{gp}$ ). The largest bodies of pegmatite are located in the southern part of the map area; in the southeastern corner they are closely associated with granodioritic rocks, whereas in the south-central part, they are enclosed by foliated, gneissic Hulayfah group rocks.

\section{GRANOPHYRE AND RELATED ROCKS}

Brick-red, coarse crystalline granophyric stocks and related, fine- crystalline volcanic and subvolcanic intrusive dikes and sills are present in the south and south central parts of the quadrangle. The intrusion of these rocks appears, in large part, to have been controlled by the Najd fault system, especially the Rawdh fault strand that crosses the southwestern part of the map area (fig.2, p. 18). Granophyric rocks, where well exposed, occur as northwest-elongate stocks (sgh) that are invariably associated with layered rhyolite, flow breccias, and ash flows, complexly and intimately intruded by rhyolitic sills (smr). The layered volcanic rocks are present only on the northeast side of the granophyre and always dip gently towards the stock. Exposures of these rocks become poor southeast, approaching the confluence of the Wadi Ar Rawdh and Wadi Asmarah; here, stocks, sills, dikes, and flows, complexely interlayered and resting upon Hulayfah group basement rocks, are mapped as felsic igneous complexes (sic). These complexes are elongate northwest, and lie adjacent to mapped faults.

The brick-red granophyre is seen in thin section to contain well developed intergrowths of quartz and potassium feldspar that is concentrated in the matrix or occurs as overgrowth on phenocrysts of feldspar. Hornblende occurs in all rocks as euhedral prisms that locally show violet shades of ploechroism. Quartz is anhedral, inequigranular to equant. Potassium feldspar and oligoclase are generally strongly altered to clays and(or) sericite.

Fine-grained, layered, porphyritic, subvolcanic rhyolite associated with granophyre consists of micrographic quartz and potassium feldspar, small, slender prisms of hornblende commonly altered to chlorite, and opaque oxides, anhedral, interstitial quartz, and interstitial to phenocrystic oligoclase.

Associated volcanic rocks include layered rhyolite, volcanic breccia with fragments as large as $30 \mathrm{~cm}$ in diameter, and vesicular rhyolitic breccia with vesicles filled with chalcedony. Breccias decrease to the northeast, away from granophyric stocks and in their place are rhyolitic rocks strikingly similar to those in the Shammar and Jibalah group rocks. 
The associated flows genetically related to the stocks appear to rest unconformably on the bevelled surface of the Hulayfah group basement complex, although the granophyric stocks appear to intrude the Hulayfah group rocks. This unconformity is perhaps best displayed in the felsic igneous complex areas (sic) where small intrusive plugs, dikes, sills, and irregular pods of granophyre are intimately mixed with Hulayfah group rocks atnd where associated, small remnants of volcanic flows appear to rest directly on the same basement.

\section{GRANITIC ROCKS}

Peralkaline granite and related monzogranite are exposed mainly in the northeast and northwest parts of the quadrangle. The geologic relations between these rock types is not always clear. An older inequigranular to conspicuously porphyritic monzogranite in the northeastern corner of the map area appears locally to be intruded by a younger, northeast-elongated pluton of pink alkali-feldspar granite and all monzogranite is intruded by young rhyolitic, alkali-rich dikes. However, in several places, the contact between the monzogranite and the alkali-feldspar granite appears to be gradational.

\section{Monzogranite}

In the northeast part of the map area, the monzogranite (mg) holds up a white, flat, grus-covered plain. The pluton is not well exposed and is commonly covered with a thin veneer of alluvial and lag gravels. The rock is seen in thin section to contain $30-35 \%$ anhedral, equant quartz, $20-25 \%$ subhedral and sericitized oligoclase, $30-35 \%$ well developed perthite, and minor green prisms of hornblende and brown tabs of biotite.

$$
\therefore .
$$

A similar pluton is present in the northwestern corner of the map area; however, this pluton is intruded only by alkali-rich, rhyolitic dikes. These rocks have a slightly pinkish cast and locally hold up small hills and knobs above an otherwise flat, grus-covered surface. This pluton is seen in thin section to contain $25-40 \%$ anhedral, equant quartz, $25-35 \%$ subhedral, sericitized ogliclase, $25-40 \%$ perthite, minor relict hornblende prisms, and biotite and muscovite tabs.

\section{Alkali-feldspar granite}

Alkali-feldspar granites (afg) are best exposed northeast of the Asmarah-Qahad graben, and occur as northeast-elongated plutons located in the center and along the southern margin of the larger monzogranite pluton. Alkali-feldspar granites clearly intrude rhyolitic to rhyodacitic flows of the "Shammar group" along the northern boundary of the map area, and bow upward and deform similar volcanic rocks along the eastern margin of the quadrangle. These rocks are seen in thin section to be equigranular-equant, and to contain $25-35 \%$ anhedral quartz, 50-60\% perthite, altered and replaced hornblende, locally minor plagioclase, and a trace of opaque oxides.

\section{Rhyolite and aplite}

Small plugs, dikes, and sills of pink- to pale red-orange, felsic, leucocratic rock (ry) intrude almost all rocks in the map area. Aphanitic rocks commonly consist of very fine crystalline micrographic quartz, alkali-feldspar, and anhedral quartz; aphanitic, porphyric rocks contain small phenocrysts of potassium-feldspar and quartz in a very fine grained, quartz-rich matrix. The mineralogy and field relations of these rocks suggest that they are related to the young granophyric and alkali granite intrusive phase in this quadrangle. 
Felsic (-) and mafic (-X-X-) dikes and sills are common throughout the map area. Almost all are aphanitic-porphyritic and they range in thickness from several centimeters to over 10 meters. Felsic rocks range in composition from rhyolite to quartz latite; mafic rocks are generally andesitic to basaltic. All show minor alteration of feldspar to clay, sericite, or epidote, and of mafic minerals to chlorite. 


\section{CENOZOIC DEPOSITS}

\section{QUATERNARY-TERTIARY BASALT}

Weakly eroded fingers of basaltic rock that invade the Ar Rawdh quadrangle from the west are continuous with the Harrat Khaybar that covers large parts of the Arabian shield west of the map area.

The absolute age of the flows is not known. Similar rocks mapped in the quadrangle to the west (Fairer, 1985a) are included with Quaternary-Tertiary basalt flows. Basaltic rock units (QTby, QTbo) in the Ar Rawdh quadrangle appear to be relatively young; they show locally well-preserved flow features, including lava tubes, pressure ridges, and polygonal solidification cracks. The long, narrow outcrop pattern of the flows suggests that they followed and were confined to presently developed, east-flowing wadi channels.

At least two flows are present in both the northwest and the southwest corners of the map area. All flows are composed of dense to vesicular olivine basalt; minimum thickness is about $3 \mathrm{~m}$.

\section{QUATERNARY DEPOSITS}

The most recent deposits in the Ar Rawdh quadrangle are represented by thick alluvial fans adjacent to local mountainous areas. These fans grade outward into broad pediment deposits composed of sand and gravel that are generally less than $0.5 \mathrm{~m}$ in thickness and that locally pinch out away from thin alluvial source areas.

Wadi deposits range in thickness from a few centimeters in the smaller braided pediment channels, to more than $15 \mathrm{~m}$ in the main channel of Wadi Asmarah. Deposits in the active Wadi Asmarah, Qahad, and Ar Rumah consist of fine sand and silt in the active channels; of fine sand, silt, and clay in areas of complex interfingering of sebkha and channel deposits; and of clays, commonly cemented by evaporite minerals, in sebkhas localized along wadi systems. All wadi deposits are associated with slightly elevated, coarse gravels interpreted to represent older, winnowed alluvium. In the central part of the Ar Rawdh quadrangle, wadi deposits are more than $8 \mathrm{~km}$ wide where the Wadi Asmarah and the Wadi Qahad merge.

Minor wind-blown sand accumulations are present in mountainous regions, mainly east of Wadi Asmarah, and may have been derived by deflation or wadi channels to the west. 


\section{STRUCTURE}

The oldest rocks in the Ar Rawdh quadrangle were strongly deformed and weakly metamorphosed during the second episode of the Hijaz tectonic cycle, 800 to $600 \mathrm{Ma}$ ago (Greenwood and others, 1976). These rocks are mainly represented in the map area by the Hulayfah group, composed of primitive crustal rocks including intermediate to mafic volcanic and clastic and minor carbonate sedimentary rocks. This layered assemblage also includes minor but important rocks that may represent parts of the nearby Hulayfah-Hamdah ophiolite belt (Delfour, 1977; Frish and Al-Shanti, 1977) that was emplaced and deformed during the collision of island-arc terranes. This suture zone has been traced southward for over $300 \mathrm{~km}$ from Hulayfah to directly south of the map boundary. The belt is composed of serpentinite, pyroxenite, gabbro, and, in the Hulayfah area, is marked by the predominance of basaltic dike rocks. The Hulayfah-Hamdah ophiolite belt, projected into the Ar Rawdh quadrangle, should be present beneath the Quaternary sediments of the Wadi Ar Rumah. The strong aeromagnetic signature that characterizes this belt to the south is present in this area; however, the ophiolitic rocks are not easily identified north of Wadi Ar Rumah. Major strike-slip faults of the $\mathrm{Najd}$ fault system intersect the projected trend of the suture zone in the southeast part of the map area, and appear to displace the suture zone to the northwest. Minor serpentinite, listwanite, gabbro, and basaltic dike swarms are present in fault-bounded wedges of Hulayfah-type rocks exposed between the Rawdh and Qahad faults. These rocks may represent the northward extension of this suture zone that was segmented and attenuated along major strike slip faults of the Najd system.

The Hulayfah group and associated rock appear to be deformed in to nearly vertical isoclinal folds and locally repeated by steep, east-dipping thrust and reverse faults. Isoclinal folds are mesoscopic to megascopic features; some of the largest folds are exposed in the southwestern corner of the map area where predominantly sedimentary facies of the Hulayfah group occupy a large fold with amplitude and wavelength measured in kilometers. This fold is associated with variously oriented disharmonic subsidiary folds on the isocline limbs. Mesoscopic folds are locally present throughout the quadrangle and their axes tend to be steeply inclined to the south. Exposures are poor in the Ar Rawdh quadrangle and the authors feel certain that only a few of the major, steeply plunging folds and associated structures likely to be present were recognized and mapped. The penetrative deformation mesoscopic character of the Hulayfah section and its juxtaposition with possible ophiolitic rocks suggests a strongly deformed basement complex. In addition to folding and faulting, all rocks were metamorphosed to the greenschist facies of regional metamorphism.

Local regional metamorphism to the amphibolite grade recrystallized these rocks along narrow zones adjacent to large granodiorite to monzogranite plutons. Well-developed foliation, migmatization, and recrystallization of these host rocks and weakly foliate fabric in the plutons are subparallel to the north- trending tectonic elements in the Hulayfah group rocks, suggesting that the intrusion and accompanying metamorphism were late syntectonic events.

The northeasternmost faults of the trans-Arabian Najd fault system, commonly believed to represent the last major phase of tectonism in the Arabian Shield, may have a long and protracted geologic history (Cole and O'Neill, 1985). Major left-lateral strike-slip displacement of Hulayfah group rocks on the Asmarah-Qahad, Tuluf, Rawdh, and smaller adjacent fault strands of this tectonic zone cross the Ar Rawdh quadrangle and show individual left separation as great as $30 \mathrm{~km}$, and a cumulative 
displacement of more than $30 \mathrm{~km}$. Displacement across the Asmarah-Qahad fault as much larger, and cannot be measured from this map area alone. Associated with the strike-slip faults are: (1) north-trending thrusts, high-angle reverse faults, and numerous small, west-verging folds with horizontal axes, and (2) east-trending highangle faults and shear zone. The compressional structures are best seen in the areas of well-layered rock of diverse lithologies. Some of the best exposures are in and adjacent to resistant beds of limestone and marble that commonly can be seen to be fault bounded, and that contain tectonic slices of mafic volcanic rocks within them. These sections are of ten repeated by east- to southeast-dipping thrust and reverse faults that locally show well-developed mullion structure. These faults and folds appear to be restricted to rocks adjacent to the strike-slip faults and are interpreted to represent secondary compressional features associated with left-lateral slip. East- to eastnortheast-trending high-angle faults are common in the map area and may represent tensional fractures associated with movement on the strike-slip faults.

The overlying, mainly horizontal, Shammar group rocks are also cut by northwest-trending faults, but show smaller amounts of lateral separation than do the older, underlying rocks. This deformation has also produced similar secondary structures: east-trending tension fractures and high angle shear zones; the northeast-trending compressional Tuluf syncline; and several minor, unmapped, and probably quite important, horizontal detachment surfaces in the basal Kuara formation in Jabal Tuluf.

The relatively localized areas of outcrop of coarse conglomerates of the lower Shammar Kuara formation suggest that these rocks were locally deposited in fault-bounded basins that extended into parts of the Ar Rawdh quadrangle. These deposits in the north-central part of the map area, near the Asmarah-Qahad graben, suggest that the Qahad fault had an early phase of dip-slip movement that help localize deposition on coarse basal conglomerate. The overlying Malha formation, however, appears to have been deposited across the entire map area, as it rests unconformably above the Hulayfah group and conformably(?) on the Kuara formation. These apparently coeval volcanic rocks show a significant increase in the sedimentary rock component in the area between the Rawdh and Qahad faults, suggesting that this area was a shallow, fault-bounded basin during Malha time. Directly northeast and southwest of this basin, the Kuara formation is absent; the volcanic rocks of the Malha formation are interlayered with only minor sedimentary rocks and rest directly on the Hulayfah group basement. It thus appears that the Shammar group rocks show significant facies changes across the $\mathrm{Najd}$ faults in the Ar Rawdh quadrangle, suggesting that during the time of deposition of these rocks, the faults bounded small, localized and important basins between adjacent fault strands.

The major structural feature in the quadrangle is the northwest-trending Asmarah-Qahad graben that contains sedimentary and volcanic rocks of the Jibalah group. The southeastern extension of this graben, in the Nuqrah quadrangle, is interpreted by Delfour (1977) as having formed during the deposition of Jibalah sediments. Rocks in the graben are gently to moderately folded locally, and are cut and truncated by the bounding Asmarah and Qahad faults. Jibalah group rocks are preserved only within the graben and their truncation by these faults suggests that at one time they extended beyond their present outcrop area. These rocks are possibly partly equivalent to the upper part of the Shammar group.

One of the last deformational episodes to affect these rocks was the diapiric rise of late alkali-granite and diorite plutons that locally fold the overlying layered rocks into domal structures. 


\section{ECONOMIC GEOLOGY}

Wadi sediment samples collected from the Ar Rawdh quadrangle do not contain anomalously high concentrations of base or precious metals (W. Miller, oral commn., 1984). However, the spacing between sample sites is large and may have not been adequate to detect small or poorly exposed areas of mineralization.

Rock-chip samples, collected from the quadrangle during the course of geologic mapping, were selected for their mineralized or altered character and are not necessarily representative of all rocks in the quadrangle. Samples were crushed and analysed for 31 elements using semiquantitative emission spectrographic and wet chemical techniques in the DGMR/USGS laboratory, Jeddah, Saudi Arabia.

Samples localities are shown in figure 2, and analyses are listed in table 1. Samples of unaltered rock types were not collected and analyzed, so that background are concentrations of elements in basic rock types not known for this area. Thirteen rock-chip samples were collected from the Ar Rawdh quadrangle and may be classified as belonging to two main groups: (1) quartz veins and mineralized fault zones; and (2) irregularly shaped altered zones containing disseminated pyrite associated with silicification and argillization.

Molybdenum was detected in four samples, and maximum values of $10 \mathrm{ppm}$ were recorded from an altered zone containing disseminated pyrite, and from a weakly mineralized fault zone. Arsenic and lead were detected in nearly all samples, and zinc, copper, and antimony were detected in all samples. The highest concentration of copper, $15,000 \mathrm{ppm}$ and two orders of magnitude greater than any other samples analysed, is from a sample collected-firom ancient diggings in the central part of the quadrangle, northwest of the village of Ar Rawdh (MODS number 1588). The highest concentrations of these elements are found mainly in vein material; the exception is zinc which also shows higher concentrations in some altered zones. Tin was detected in only one sample, a quartz vein that yielded $30 \mathrm{ppm}$; tungsten was not detected in any samples. Both gold and silver were detected in all but one sample. Gold concentrations average $0.05 \mathrm{ppm}$; silver concentration average is $0.59 \mathrm{ppm}$ with a maximum value of $4.4 \mathrm{ppm}$ detected from the ancient prospect near Ar Rawdh.

It is clear from table 1 that only one area sampled contains anomalously high concentrations of some elements--the ancient diggings northwest of the village of Ar Rawdh. No other areas of major base and precious metal mineralization are exposed in the Ar Rawdh quadrangle. Of some interest, however, is that hydrothermal mineralization, even though weak, appears to be structurally controlled. Argillization and associated dissemination of iron sulfides are common in volcanic and volcanoclastic rocks adjacent to and between the Rawdh and Asmarah faults; and strong silicification of Jibalah group rocks characterizes the southeastern extent of the Qahad and Asmarah faults. This hydrothermal mineralization is probably related to alkali-granite intrusive activity that occurred in the Arabian shield in latest Proterozoic time.

Stratabound sulfide mineralization, formed during the early accretionary history of : the shield and confined to the strongly deformed Hulayfah group rocks, was not detected in the quadrangle. This is somewhat surprising because important stratabound mineral occurrences are present in these rocks directly to the south in the Nuqrah quadrangle (Delfour, 1977). The apparent absence of mineralization may be due to truncation of the north-trending mineralized Hulayfah group rocks by northwesttrending faults that cut diagonally across the Ar Rawdh quadrangle. Shearing of 


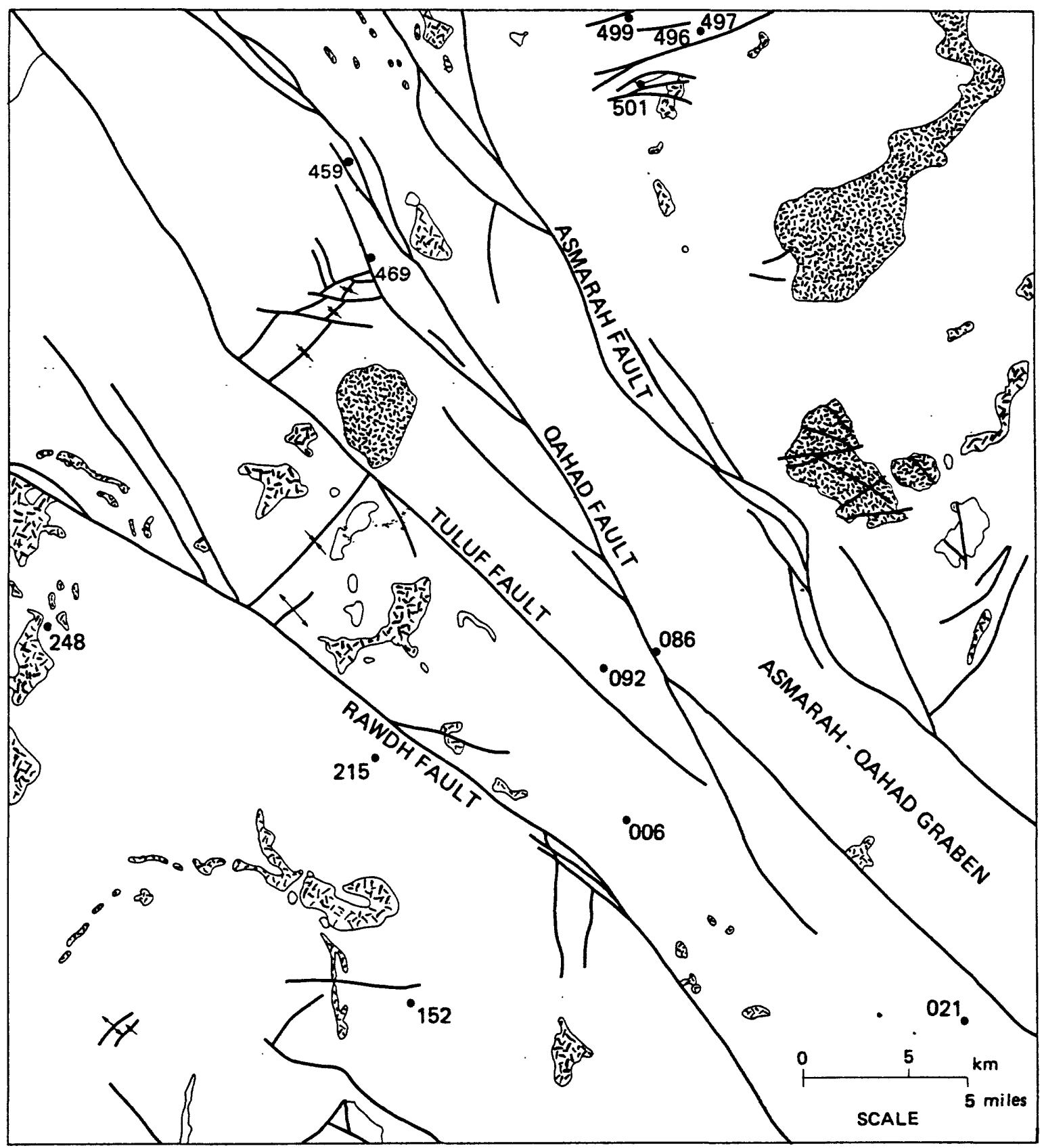

Figure 2.- Geologic sketch map of the Ar Rawdh Quadrangle showing faults (heavy lines), folds, and late Proterozoic granitic and dioritic rocks (patterned). Numbers refer to localities of rock chip samples analyzed for base and precious metals; number on map refers to last three digits of the RASS field number shown on table 1 . 

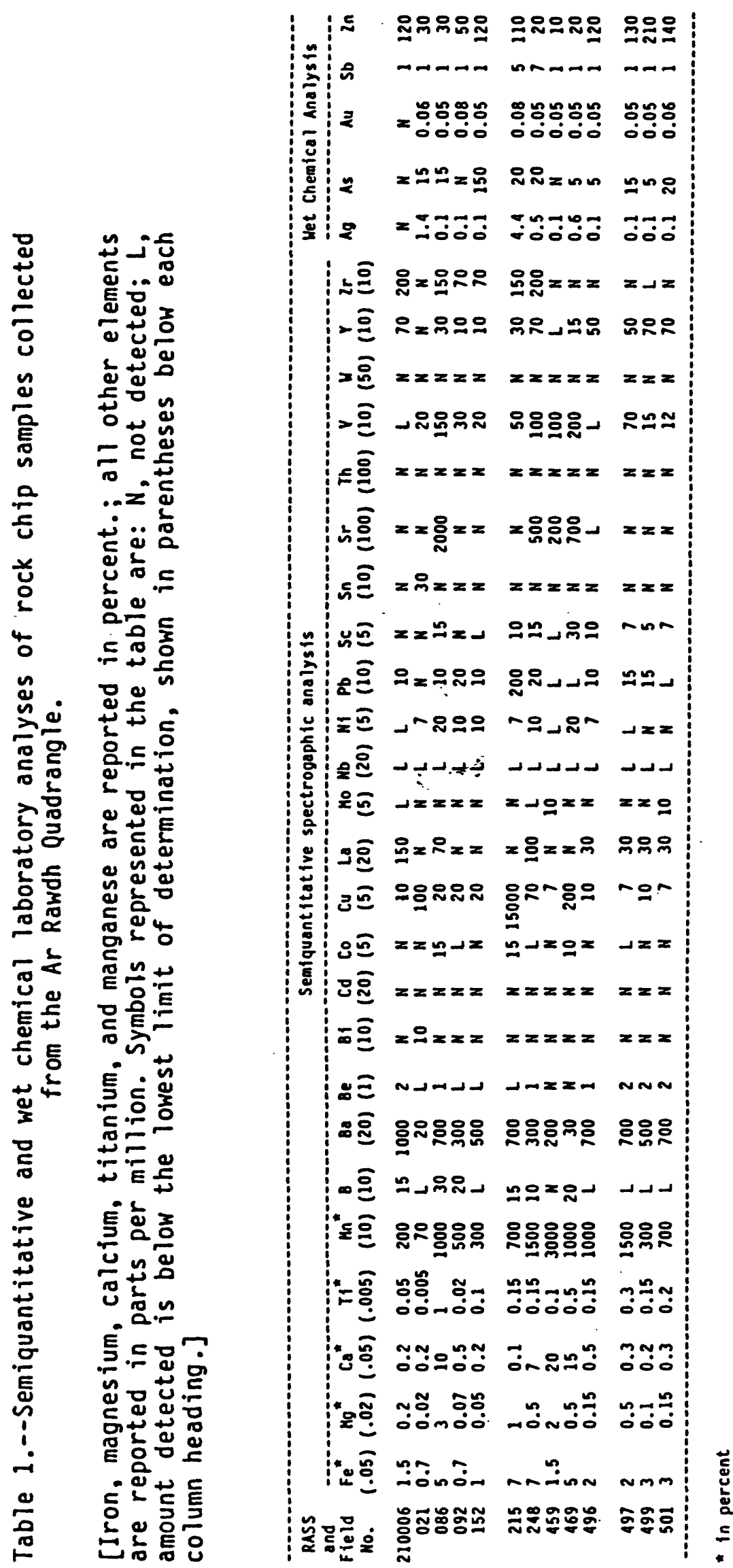
rocks between the Rawdh and Asmarah faults and a component of left slip that may exceed $30 \mathrm{~km}$, may have so strongly sheared, attenuated, and deformed potential mineralized zones so as to make them subeconomic and difficult to locate, or may have displaced the mineralized zones an unknown distance to the northwest.

In summary, rocks of the Ar Rawdh quadrangle show clear evidence of hydrothermal alteration and weak mineralization. Control of mineralization by northwest-trending faults is suggested here, similar to other mineralized areas on the Arabian shield (Moore and Al Shanti, 1976). Data from this study indicate that economic deposits did not form, have been eroded away, or remain too deeply buried to be detected. The potential for stratabound sulfide deposits confined to older Hulayfah group rocks in this area seems high, for such deposits are known from the Nuqrah quadrangle directly to the south; however, offset and deformation along northwest-trending strands of the $\mathrm{Najd}$ fault system may have displaced these potential deposits to the northwest, beyond the map area boundaries, or so strongly deformed them as to rendered them subeconomic, if they were ever present.

\section{DATA STORAGE}

Data file USGS-DF-04-37 (O'Neill and Ferris, 1984) has been established for the storage of field and laboratory data used in this report. 


\section{REFERENCES CITED}

Bowden, R. A., 1982, Reconnaissance assessment of the Hulayfah-Zarghat area, northeast Hijaz: Saudi Arabian Deputy Ministry for Mineral Resources Open-File Report RF-OF-02-14, 12 p.

Brown, G. F., and Jackson, R. O., 1960, The Arabian Shield: International Geological Congress, 21 st, Copenhagen, 1960, Proceedings, sec. 9, p. 69-77.

Brown, G. F., Layne, H. M., Jr, Goudarzi, G. H., and Maclean, W. H., 1963, Geologic map of the northeastern Hijaz quadrangle, Kingdom of Saudi Arabia: U.S. Geological Survey Miscella- neous Geologic Investigations Map I-205A, scale $1: 500,000$.

Cole, J. C., and O'Neill, J. M. 1985, Late Proterozoic-early Paleozoic displacement history along the Halaban-Zarghat fault zone, Kingdom of Saudi Arabia: Unpublished data on file at the U.S. Geological Survey Mission, Jeddah, Saudi Arabia.

Delfour, J., 1970, The Jibalah Group, A new unit of the Arabian Shield: Bureau de Recherches de Geologiques et Minieres (Saudi Arabian Mission) Report 70-JED-4, 31 p.

1977, Geology of the Nuqrah Quadrangle, sheet 25E, Kingdom of Saudi Arabia: Saudi Arabian Directorate General of Mineral Resources Geologic Map GM-28, 32 p., scale $1: 250,000$.

Fairer, G. M., 1985a, Reconnaissance geology of the Jabal al Usayfir quadrangle, sheet 26/40 C, Kingdom of Saudi Arabia: Saudi Arabian Deputy Ministry for Mineral Resources Open-File Report USGS-OF-05-15, scale, 1:100,000. Also, 1985, U.S. Geological Survey Open-File Report 85-

.....-.-, 1985b, Reconnaissance geology of the Ash Shamila quadrangle, sheet 26/40 A, Kingdom of Saudi Arabia: Saudi Arabian Deputy Ministry for Mineral Resources Open-File Report USGS-OF-05-16, scale, 1:100,000. Also, 1985, U.S. Geological Survey Open-File Report 85-

Frish, W., and Al-Shanti, A., 1977, Ophiolite belts and the collision of island arcs in the Arabian Shield: Tectono- physics, v. 43, p. 293-316.

Greenwood, W. W., Hadley, D. G., Anderson, R. E., Fleck, R. J., and Schmidt, D. L., 1976, Late Proterozoic cratonization in southwestern Saudi Arabia: Philosophical Transactions of the Royal Society of London, Series A, v. 280, p. 517-527.

Hadley, D. G., 1973, Geology of the Sahl al Matran quadrangle, northwestern Hijaz, Kingdom of Saudi Arabia: Saudi Arabian Directorate General of Mineral Resources Geologic Map GM-6, 14 p., scale 1:100,000.

Kemp, J., Pallaton, C., and Calvez, J. Y., 1980, Geochronological investigations and geologic history in the Precambrian of northwestern Saudi Arabia: Bureau de Recherches Geologiques et Minieres, Saudi Arabian Mission Open-File Report BRGM-OF-01-1, 120 p.

O’Neill, J. M., and Ferris, D. C., 1984, Data file USGS-DF-04-37, U.S. Geological Survey Saudi Arabian Mission 
Quick, J. E., 1983, Reconnaissance geology of the Ghazzalah quadrangle, sheet 26/41 A, Kingdom of Saudi Arabia: Saudi Arabian Deputy Ministry for Mineral Resources Open-File Report USGS-OF- 03-91, 44 p., scale 1:100,000. A1so, 1983, U.S. Geological Survey Open-File Report 83-331.

........, 1984, Reconnaissance geology of the Zarghat quadrangle, sheet 26/40 B, Kingdom of Saudi Arabia: Saudi Arabian Deputy Ministry for Mineral Resources Open-File Report USGS-OF- 04-28, 37 p., scale 1:100,000. Also, 1984, U.S. Geological Survey Open-File Report 84-794.

-.....-., 1985, Reconnaissance geology of the As Sulaymi quadrangle, sheet 26/41 C, Kingdom of Saudi Arabia: Saudi Arabian Deputy Ministry for Mineral Resources Open-File Report USGS- OF-05-4, 19 p., scale 1:100,000. Also, 1985, U.S. Geological Survey Open-File Report 85-

Schmidt, D. L., Hadley, D. G., Greenwood, W. R., Gonzalez, L., Coleman, R. G., and Brown, G. F., 1973, Stratigraphy and tectonism of the southern part of the Precambrian shield of Saudi Arabia: Saudi Arabian Directorate General of Mineral Resources Bulletin No. 8, 13 p.

Schmidt, D. L., Hadley, D. G., and Stoeser, D. B., 1979, Late Proterozoic crustal history of the Arabian Shield, southern Hijaz province, Kingdom of Saudi Arabia, in Evolution and mineralization of the Arabian-Nubian Shield, v. 2: Oxford-New York, Pergamon Press, p. 41-58 (King Abdulaziz University, Institute of Applied Geology, I.A.G. Bulletin No. 3, v. 2). 
APPENDIX 


\section{APPENDIX}

APPENDIX-- Stratigraphic sections of the upper part of the Kuara formation (A) and the upper and lower parts of the Malha formation (B). Measured at Jibal Tuluf.

\section{SYMBOLS USED FOR STRATIGRAPHIC SECTIONS}

- จนธㅁ Flow breccia

Lahar

$\approx=-$ Layered ash flow

$\checkmark^{2} \quad$ Rhyolitic sill

$\hat{\wedge} \quad$ Andesitic sill

海- Diorite--Small- to medium-grained

$\rightleftharpoons$ Diorite--Containing large plagioclase lathes

oulder conglomerate--Poorly sorted

8:8: Pebble conglomerate

$\therefore \quad$ Sandstone

Zi- Siltstone

$=\equiv$ Shale

$\infty$ Pumice

* Phenocryst

$\triangle_{\Delta}{ }^{\prime} \quad$ Lithic fragment

$\Leftrightarrow$ Exotic blocks

$0 . \%$ Concretions 

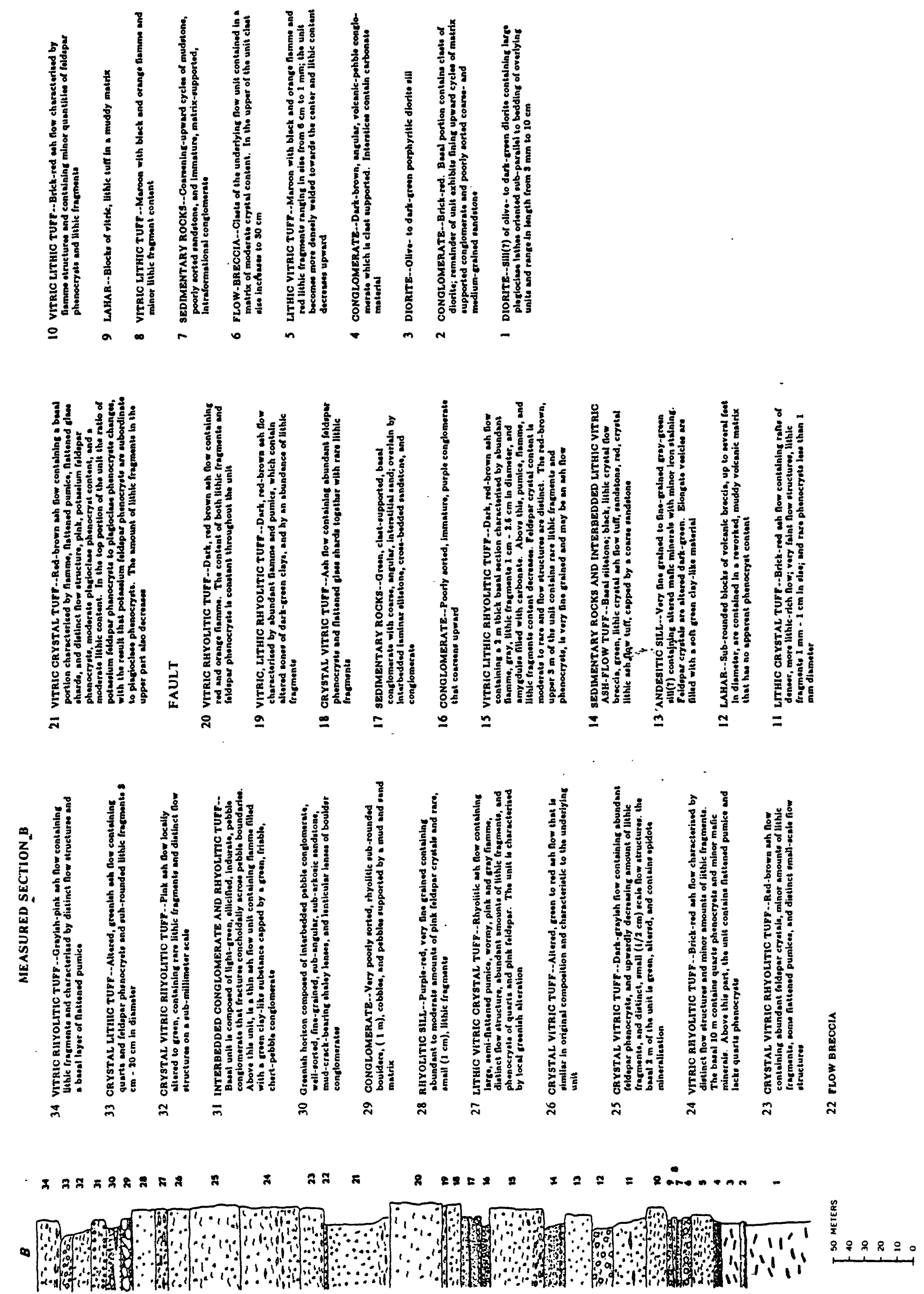